\title{
GAMBARAN HISTOPATOLOGI LAMBUNG TIKUS WISTAR (Rattus norvegicus) YANG DIBERIKAN VITAMIN C (Asam askorbat) DOSIS TINGGI
}

\author{
${ }^{1}$ Juwita P S. Baharuddin \\ ${ }^{2}$ Meilany F. Durry \\ ${ }^{2}$ Poppy M. Lintong
}

\author{
${ }^{1}$ Kandidat Skripsi Mahasiswa Fakultas Kedokteran Universitas Sam Ratulangi Manado \\ ${ }^{2}$ Bagian Patologi Anatomi Fakultas Kedokteran Universitas Sam Ratulangi Manado \\ Email: Puspitajuwita@gmail.com
}

\begin{abstract}
Background: Vitamin C is one of the chemicals which are acidic and therefore is able to irritate the stomach lining if consumed in excessive amount. Objective: To reveal the histopathological features of the stomach of wistar rats supplemented with high doses of vitamin C. Method: Experimental study employing eight wistar rats divided into three groups. Rats in group A were fed with regular pellets for 12 days. Rats in group B were fed with regular pellets and were supplemented with vitamin $C$ at $6 \mathrm{mg} /$ day for 12 days. Rats in group $C$ were fed with regular pellets and were supplemented with vitamin $\mathrm{C}$ at $8 \mathrm{mg} /$ day for 12 day. Results: Rats in group A showed normal stomach features. Rats in group B revealed PMN inflammatory cells and hiperemy on the mucosal lining, submucosa, and muscularis mucosae. Moreover, edema on the mucosal lining was also seen in the rats in this group. Similar histopathological features were also demonstrated by the rats in group C. In this group the number of PMNs and hiperemy was greater than that of group B; in addition, cell regeneration was also seen in this group. Conclusion: Supplementation of high doses of vitamin $\mathrm{C}$ at $6 \mathrm{mg} / \mathrm{kg}$ and $8 \mathrm{mg} / \mathrm{kg}$ of body weight per day for 12 days may lead to changes in histopathological features of the stomach of wistar rats.
\end{abstract}

Keywords: acute gastritis, vitamin C.

\begin{abstract}
Abstrak: Latar Belakang: vitamin C merupakan salah satu bahan kimia yang bersifat asam, sehingga apabila dikonsumsi berlebihan dapat mengiritasi lambung. Tujuan: Untuk mengetahui gambaran histopatologi lambung tikus wistar yang diberikan vitamin $\mathrm{C}$ dosis tinggi. Metode: Penelitian eksperimental dengan 8 ekor tikus wistar dibagi menjadi 3 kelompok. Kelompok A diberikan pelet biasa selama 12 hari. Kelompok B diberikan pelet biasa dan vitamin C 6 mg/hari selama 12 hari. Kelompok C diberikan pelet biasa dan vitamin C 8 mg/hari selama 12 hari. Hasil: Pada kelompok A didapatkan gambaran lambung yang normal. Kelompok B terlihat sel-sel radang PMN dan hiperemi pada lapisan mukosa, sub mukosa dan muskularis, pada kelompok ini juga terlihat edema pada lapisan mukosa. Kelompok C terlihat pada lapisan mukosa, submukosa dan muskularis adanya sel-sel radang PMN dan hiperemi yang lebih banyak dibandingkan kelompok B, selain itu juga terlihat regenerasi sel. Kesimpulan: Pemberian vitamin C dosis tinggi yaitu $6 \mathrm{mg} /$ hari dan $8 \mathrm{mg} /$ hari selama 12 hari dapat mengakibatkan perubahan gambaran histopatologi lambung.
\end{abstract}

Kata Kunci: Gastritis akut, vitamin C.

Vitamin merupakan senyawa organik yang sangat diperlukan oleh tubuh. Vitamin adalah bahan esensial yang dibutuhkan untuk membantu kelancarkan penyerapan zat gizi dan proses metabolisme. ${ }^{1,2}$ Asam askorbat atau lebih dikenal dengan vitamin 
C merupakan salah satu vitamin yang dibutuhkan oleh tubuh. Vitamin C merupakan vitamin yang larut dalam air, vitamin ini juga merupakan reduktor kuat. ${ }^{2,3}$ Vitamin C mempunyai banyak fungsi yang banyak bagi tubuh, salah satunya adalah meningkatkan daya tahan tubuh, karena begitu banyak fungsi dari vitamin $\mathrm{C}$ ini sehingga masyarakat berpendapat bahwa fungsi dari vitamin $\mathrm{C}$ akan bertambah seiring dengan meningkatnya asupan vitamin C. Vitamin C dosis tinggi atau lebih dari $1000 \mathrm{mg} /$ hari dapat menyebabkan efek samping diare dan juga dapat mengiritasi lambung. ${ }^{3,4}$

\section{METODE PENELITIAN}

Penelitian ini merupakan penelitian eksperimental laboratorik, dilakukan pada periode Oktober 2012 sampai januari 2013 di Laboratorium Patologi Anatomi Fakultas Kedokteran Universitas Sam Ratulangi, Manado. Penelitian menggunakan 8 ekor tikus wistar jantan dan betina, berumur 2-3 bulan dan berat badan tikus 200-250 gram, yang dibagi menjadi 3 kelompok, yaitu kelompok A diberikan makan pelet standar selama 12 hari, kelompok B diberikan vitamin C 6 mg/perhari (1500/kgBB/hari) selama 12 hari dan pelet standar, dan kelompok C diberikan vitsmin C 8 $\mathrm{mg} /$ perhari (2000 mg/kgBB/hari) selama 12 hari dan pelet standar. Ketiga kelompok diterminasi hari ke-13. Vitamin C yang digunakan adalah vitamin $\mathrm{C}_{\mathrm{IPI}}{ }^{\circledR}$ dengan sediaan tablet berisi vitamin C $50 \mathrm{mg}$. Dosis yang digunakan $6 \mathrm{mg}$ dan $8 \mathrm{mg}$ yang diberikan selama 12 hari. Vitamin C diberikan peroral. Sebelumnya vitamin C digerus sampai berbentuk serbuk, kemudian dilarutkan dengan aquades sebanyak $1 \mathrm{ml}$, setelah itu dengan menggunakan semprit insulin $1 \mathrm{ml}$ yang ujungnya menggunakan selang Naso Gastric Tube (NGT) pediatri no. 5. NGT tersebut dimasukkan ke dalam mulut tikus wistar secara hati-hati sampai masuk ke lambung, dimasukan secara perlahan untuk menghindari refluks dan bahaya aspirasi. Tikus wistar diterminasi pada hari ke-13, kemudian dilakukan pengambilan jaringan lambung setelah jaringan diambil dilakukan pengamatan secara makroskopik dan tahap pemotongan, fiksasi, dehidrasi dan dibuat blok parafin dan dilakukan pewarnaan Hematoksilin Eosin (HE). Sediaan jaringan diamati dengan mikroskopik cahaya.

\section{HASIL PENELITIAN}

\section{Gambaran Makroskopik}

Gambaran makroskopik lambung tikus wistar kelompok perlakuan memperlihatkan warna yang sama dengan tikus kontrol. Konsistensinya juga sama antara tikus perlakuan dan kontrol, sedangkan berat dan panjang sedikit bervariasi antara satu kelompok dengan kelompok lain.

\section{Gambaran Mikroskopik}

\section{Kelompok A (kontrol)}

Kelompok A (kontrol negatif) yang diberikan pelet biasa selama 12 hari didapatkan gambaran lambung tikus wistar yang normal. Pada sediaan lambung ini tampak lapisan mukosa, submukosa, muskularis dan serosa yang normal. Pada lapisan mukosa, submukosa, muskularis dan serosa tidak ditemukan sel-sel radang PMN dan hiperemi.

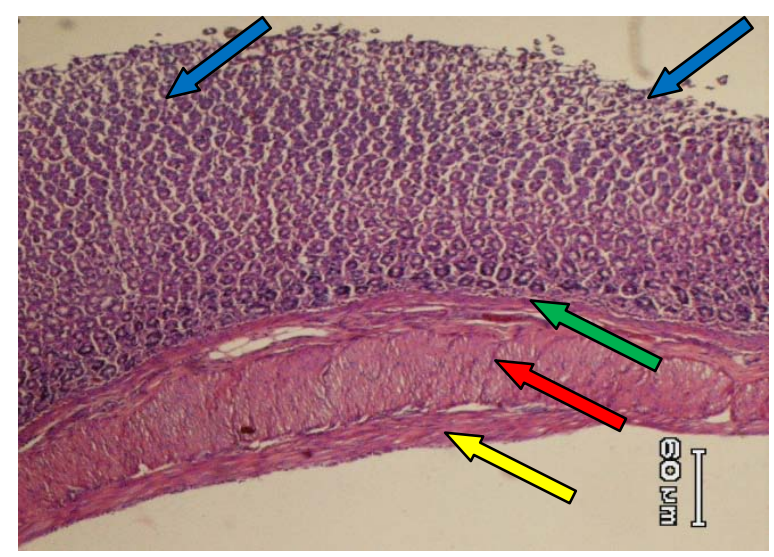

Gambar 1. Gambaran mikroskopik lambung tikus wistar di atas diberikan pelet biasa selama 12 hari, terlihat lapisan mukosa (panah biru), submukosa (panah hijau), muskularis (panah merah) dan serosa (panah kuning) yang normal. Pembesaran 4x10. 


\section{Kelompok B ( perlakuan 1)}

Kelompok B (kelompok tikus perlakuan 1) yang diberikan vitamin C 6 mg perhari selama 12 hari dan pelet standar. Pada sediaan ini tampak adanya sel-sel radang PMN pada lapisan mukosa, submukosa dan muskularis. Selain itu juga terlihat hiperemi pada lapisan mukosa dan submukosa. Pada lapisan mukosa juga terlihat adanya edema.

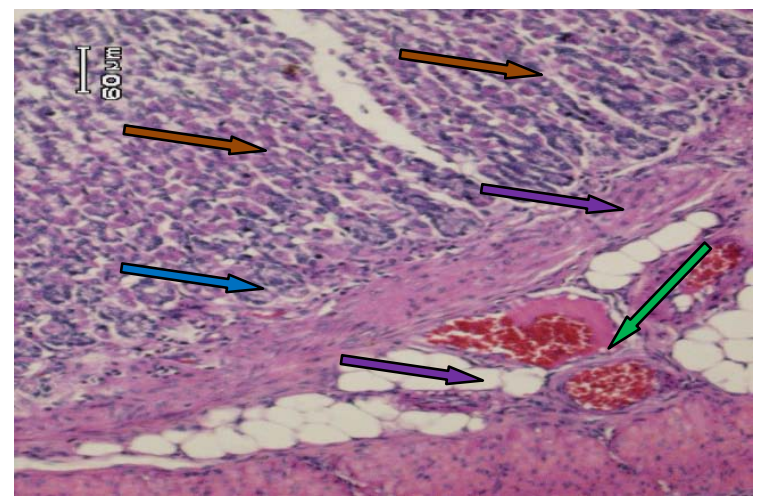

Gambar 2. Gambaran mikroskopik lambung tikus wistar, tampak pada lapisan mukosa terdapat sel-sel radang PMN (panah coklat) dan hiperemi (panah biru). Pada lapisan submukosa juga terdapat hiperemi (panah hijau) dan sel radang (panah ungu). Pembesaran 20x10.

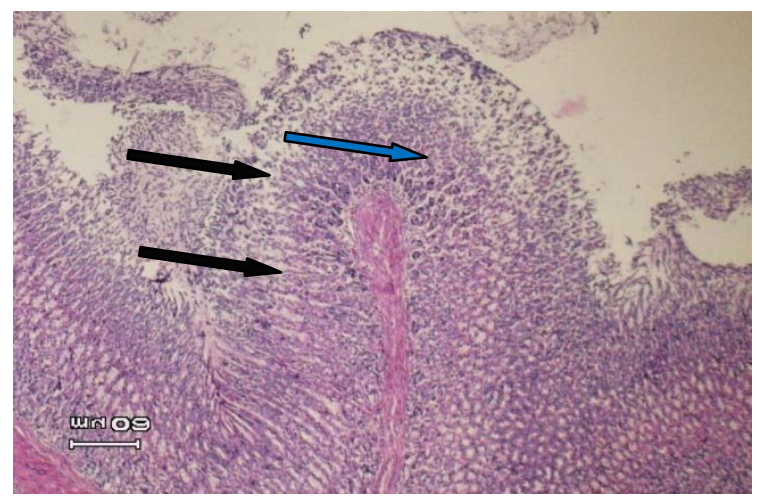

Gambar 3. Gambaran mikroskopik lambung tikus wistar yang diberikan vitamin C $6 \mathrm{mg}$ selama 12 hari. Tampak pada lapisan mukosa sel-sel radang PMN (panah biru) dan lapisan mukosa yang edema (panah hitam). Pembesaran 10x10.

\section{Kelompok C (perlakuan 2)}

Kelompok C (kelompok tikus perlakuan 2) yang diberikan vitamin C $8 \mathrm{mg} /$ hari selama 12 hari. Pada sediaan terdapat perubahan pada lapisan mukosa, submukosa dan muskularis yakni ter-dapat selsel radang PMN dan hiperemi yang lebih banyak, selain itu juga pada perlakuan ini terlihat regenerasi sel-sel epitel permukaan mukosa lambung.

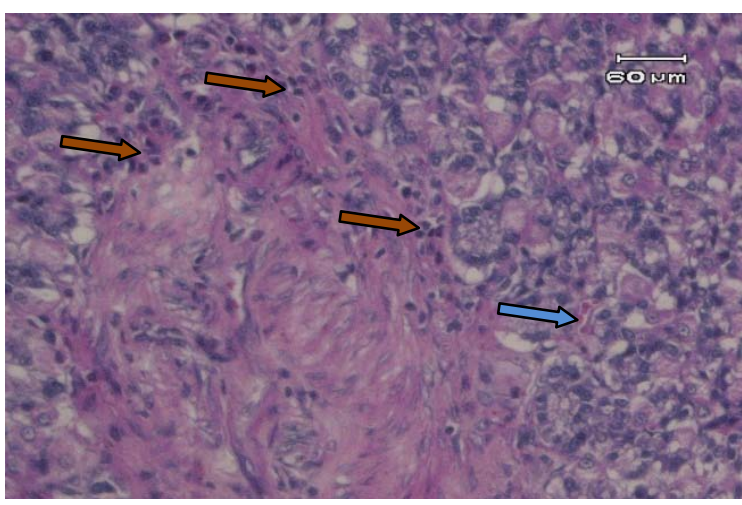

Gambar 4. Gambaran mikroskopik lambung tikus wistar yang diberikan vitamin C $8 \mathrm{mg}$ selama 12 hari. Tampak sel-sel radang PMN (panah coklat) dan hiperemi pada lapisan mukosa (panah biru). Pembesaran 20x10.

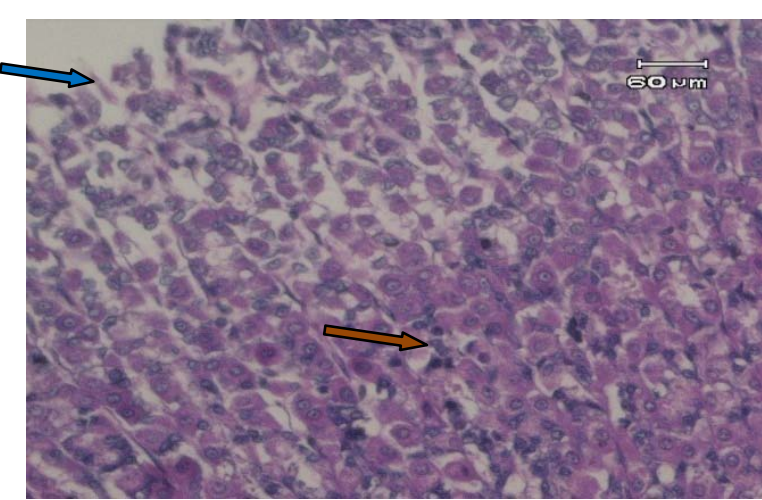

Gambar 5. Gambaran mikroskopik lambung tikus wistar yang diberikan vitamin C $8 \mathrm{mg}$ selama 12 hari. Tampak pada lapisan mukosa sel-sel radang (panah coklat) dan terjadi regenerasi (panah biru). Pembesaran 40x10. 


\section{BAHASAN}

Pada tikus perlakuan pertama kelompok B dengan pemberian vitamin C 6 $\mathrm{mg} /$ hari selama 12 hari, secara mikroskopik lapisan mukosa, submukosa dan muskularis lambung terdapat sel-sel radang dan juga terlihat hiperemi pada lapisan mukosa dan submukosa. Sel-sel radang dan hiperemi yang tampak ini terjadi karena vitamin $\mathrm{C}$ dosis tinggi yang diberikan merupakan cairan bersifat asam yang menyebabkan iritasi pada lambung dan mencetuskan reaksi radang akut. ${ }^{7}$ Terjadinya hiperemi karena pada saat jejas pembuluh darah vasodilatasi, aliran darah akan bertambah dan tekanan hidrostatik meningkat, akibatnya cairan plasma dan protein akan keluar. Cairan dan protein yang keluar ke interstisial mengakibatkan terjadinya edema. Hal ini mengakibatkan viscositas darah meningkat dan aliran darah lambat. ${ }^{8}$

Pada perlakuan 2 kelompok $\mathrm{C}$ dengan pemberian vitamin $\mathrm{C}$ 8mg/hari selama 12 hari, tampak lapisan mukosa dan muskularis terdapat sel-sel radang yang lebih banyak dan juga hiperemi pada lapisan submukosa. Pada perlakuan ini juga terlihat adanya regenerasi sel-sel epitel permukaan mukosa, hal ini secara fisiologis dikarenakan jika bikarbonat meningkat atau memperlancar aliran darah ke mukosa lambung sehingga dapat membantu regenerasi sel epitel lambung yang mengalami kerusakan ${ }^{9,10}$ Regenerasi yang terjadi pada sel epitel normalnya akan terjadi dalam 2 sampai 6 hari. $^{8}$

\section{SIMPULAN}

Berdasarkan hasil penelitian ini, dapat dismpulkan bahwa pemberian vitamin $C$ dosis tinggi $6 \mathrm{mg} / \mathrm{kg}$ BB dan $8 \mathrm{mg} / \mathrm{kg} \mathrm{BB}$ perhari selama 12 hari dapat mengakibatkan gastritis akut ditandai dengan adanya sel-sel radang PMN, hiperemi pada lapisan mukosa, submukosa, muskularis dan serosa. Hiperemi pada lapisan mukosa dan submuksa, selain itu juga terjadi edema dan regenerasi pada lapisan mukosa.

\section{UCAPAN TERIMA KASIH}

Ucapan terima kasih kepada DR. Dra. Fatimawali, Apt, MSi dan dr. Carla Kairupan, $\mathrm{PhD}$, serta semua pihak yang secara langsung maupun tidak langsung yang telah memberi ide maupun gagasan kepada penulis singga penulis dapat menyelesaikan penelitian ini.

\section{DAFTAR PUSTAKA}

1. Paath EF, Rumdasih Y, Eferyati. Zat-Zat Gizi. In: Kesehatan Repoduksi. Jakarta: EGC, 2004; p.23-4.

2. Sediaoetama AD. Vitamin. In: Ilmu Gizi Untuk Mahasiswa dan Profesi Jilid 1. Jakarta: Dian Rakyat, 2008; p.131-4.

3. Yulianasari IA, Aprianti A, Angkasa D, Vivaldy A. Pro dan Kontra Dosis Tinggi Vitamin C dan Pengaruh Terhadap Ginjal. PKM Institut Pertanian Bogor; 2008.

4. Dewato HR. Vitamin dan Mineral. In: Farmakologi dan Terapi (Edisi Kelima). Jakarta: FKUI, 2009; p.769-79.

5. Sudiono J, Kurniadhi B, Hendrawan A, Djimantoro B. Radang dan Pemulihan Jaringan. In: Ilmu Patologi. Jakarta: EGC, 2003; p.81-92.

6. Robbins and Cotran. Phatology of Disease (Eigth Edition). Philadelphia: saunders Elsevier.2010. p: 774-5.

7. Mitchell N Richard, Cotran S Ramzi. Inflamasi Akut dan Kronik. In: Buku Ajar Patologi Volume 1. Jakarta: Penerbit Buku Kedokteran EGC, 2007; p.37-38.

8. Puspitasari DA. Gambaran histopatologi lambung tikus wistar akibat pemberian asam asetil salesilat. Bogor: Fakultas Kedokteran Hewan Bogor, 2008.

9. Hirlan. Gastritis. In: Buku Ajar Ilmu Penyakit Dalam 1 (Edisi Kelima). Jakarta: Pusat Penerbitan Departemen Ilmu Penyakit Dalam FKUI, 2009; p.509-10. 